\title{
Caterina Martínez Martínez, Origen i evolució dels connectors de contrast en català, Alacant / Barcelona, Institut Interuniversitari de Filologia Valenciana / Publicacions de l'Abadia de Montserrat, «Biblioteca Sanchis Guarner», 202I, 247 p., ISBN: 978-84-919I-I52-4.
}

Origen i evolució dels connectors de contrast en català és una obra que mostra el bon estat dels estudis de gramàtica històrica del català i que fa palesa la importància de l'escola sorgida entorn de la Universitat d'Alacant com un dels motors principals d'aquestes investigacions. L'autora, Caterina Martínez Martínez, traça amb profunditat i rigor la història de quatre connectors del català: nogensmenys, tanmateix, a despit de, malgrat \{ø/de/tot/això\}. L'evolució de tots quatre està condicionada per la trajectòria mateixa de la llengua catalana, marcada pel període de la Decadència que va venir seguit per la Renaixença i la creació d'un model de llengua culta, on l'autoritat de Pompeu Fabra va resultar clau, també en la conformació del sistema de les marques de connexió.

Des d'un punt de vista de la teoria lingüística, l'obra segueix el paradigma de la Lingüística Cognitiva, combinat amb una aproximació pragmaticodiscursiva que permet analitzar la funció textual de les peces estudiades. Així, l'estudi de la gramaticalització dels connectors es fa des de la Teoria de la Inferència Invitada del Canvi Semàntic (Traugott \& Dasher 2002) i la Teoria del Prototip basada en el Principi de Semblança de Família (Geeraerts 1997). Aquesta aproximació es complementa amb els postulats de la Teoria de l'Argumentació d'Anscombre \& Ducrot (1994) i de la Pragmàtica del Discurs, de la qual es prenen els conceptes de subjectivització (Traugott 20IO) i intersubjectivització (Nuyts 2005; Narrog 2012).

La línia cognitivista en què s'inscriu l'obra va acompanyada d'una aproximació a l'estudi del canvi lingüístic basada en l'ús. En aquest sentit, l'autora fa un rastreig exhaustiu de l'evolució de les peces que estudia en els diferents corpus existents del català. Així, extreu les seves dades del Corpus Informatitzat Multilingüe de Textos Antics i Contemporanis (CIMTAC), constituït pel Corpus Informatitzat per a la Gramàtica 
del Català Antic (CIGCA) — que inclou textos des del segle XII fins al XVI- i pel Corpus Informatitzat per a la Gramàtica del Català Modern (CIGCMod) —format per documents redactats del I60I al I833. També s'ha consultat el Corpus Informatitzat del Català Antic (CICA) —integrat per obres datades entre els segles XI i XVI. Per últim, per al període comprés entre l'inici de la Renaixença i les darreries del segle passat, Caterina Martínez ha recorregut al Corpus Textual Informatitzat de la Llengua Catalana (CTILC). A més a més, complementa la seva tasca amb la lectura d'obres lexicogràfiques i analitza també altres textos que enriqueixen els corpus i els testimonis lexicogràfics consultats, incloent-hi les traduccions d'obres estrangeres al català. La combinació del paradigma cognitivista amb una metodologia fonamentada en una cerca exhaustiva dels connectors analitzats aporta a aquest estudi un rerefons conceptual i un bagatge d'anàlisi de dades que donen gran validesa a les conclusions a què s'hi arriba.

Aquesta monografia està articulada en cinc capítols. L'obra comença amb una llista de les abreviatures, les sigles i els símbols emprats i el pròleg de Sandra Montserrat, professora de la Universitat d'Alacant. Els agraïments que apareixen a continuació van seguits dels cinc capítols que integren l'obra, que es tanca amb una extensa bibliografia, organitzada per temes, i un índex que facilita la recuperació d'autors, conceptes, figures i gràfics.

El capítol que obre el llibre consisteix en una introducció que explicita el model teòric en què s'insereix la investigació que la professora Caterina Martínez ha dut a terme. S'aclareixen conceptes i es descriuen els corpus que s'han fet servir i el procediment de treball seguit.

El segon capítol és una introducció teòrica a la gramaticalització del CONTRAST. Es comença per explicitar els possibles ètims per a l'expressió d'aquest concepte, tot seguint el treball ja clàssic de König (1985), que va elaborar una taxonomia de les fonts possibles del contrast. D'aquestes fonts eventuals, a Caterina Martínez li interessen les de CÀLCUL i d'Emoció. Un cop descrits aquests valors i explicada la via evolutiva que porta de les nocions de CÀLCUL i EMOCIÓ a la de CONTRAST, s'hi fa una descripció acurada de la funció argumentativa de CONTRAST, descrita com a estratègia contraargumentativa. L'autora considera que el CONTRAST Implica una ADVERSATIVITAT CONCESSIVA. D'aquesta manera, inclou dins del contrast les relacions adversatives, que suposen una oposició forta entre dos estats de coses, i les concessives, marcades per assenyalar que l'oposició no és forta, contràriament al que es podria pensar. A grans trets, els connectors es distribueixen segons expressin significats concessius o adversatius. Però també n'hi ha que aglutinen tots dos valors: es tracta dels connectors parentètics d' [ADVERSATIVITAT CONCESSIVA], això és, connectors parentètics de contrast, que «expressen una oposició que pot ser forta o no» (p. 3i). 
El capítol tercer se centra en l'evolució de dos connectors que tenen el seu origen en el concepte de CÀlCul. L'autora comença per estudiar l'evolució de noresmenysnogensmenys. La primera forma és l'originària del català; la segona és fruit d'una reelaboració fabriana. Des de les seves primeres documentacions, noresmenys es troba emprat amb valor de càlcul. Aquest sentit originà un significat additiu, present en català des del segle XIII fins a finals del XVI. El significat additiu afegia matisos continuatius, finalitzadors i confirmatius. En tots aquests casos, es podia rastrejar en noresmenys un sentit de preferència per la informació que introduïa, i aquest matís afavorí que aparegués juntament amb marcadors de contrast, que van contribuir al darrer pas evolutiu del connector, que va acabar especialitzat amb sentits contrastius — aquests es comencen a intuir des del segle Xv. Molt possiblement, l'origen del significat contrastiu partí de la noció confirmativa, que permetia contrastar el que es diria després de noresmenys i el que s'havia presentat abans. La forma noresmenys es documenta per últim cop al segle XVI i va ser descartada durant l'etapa normalitzadora de començaments del segle xx, quan fou substituïda per la forma contemporània nogensmenys, propugnada per Pompeu Fabra.

A continuació, l'autora s'ocupa del connector tanmateix, originat en una construcció que lliga el quantificador tan a l'adjectiu emfatic mateix, seguits d'un substantiu. La construcció s'utilitzà amb valor emfátic per expressar que el referent denotat pel substantiu es dona en la mateixa quantitat que un altre referent abans citat (si de part sua produbia tants mateyx testimonis qui diguessen lo contrari). Durant els segles XIV-XVIII es documentà la seqüència tan mateix amb substantius implícits. El conjunt tenia el significat de 'la mateixa quantitat, el mateix'. El valor de càlcul es perdé en el segle XVIII, però des del XVII es rastregen valors pont, amb un significat a mig camí entre el càlcul i l'addició de confirmació, d'on s'arriba, en una segona fase evolutiva, que arrenca del segle Xvin, a un valor additiu, amb matisos que van des de la confirmació ('efectivament'; emprat sobretot com a marcador de pregunta o resposta confirmatòria) a la resolució ('finalment'). L'última etapa evolutiva suposa el desenvolupament, des dels valors additius, d'un marcador de contrast de sentit adversatiu-concessiu. Aquesta evolució es fonamenta en l'aparició de tanmateix amb marcadors concessius, que permet una transferència de significats que, segurament, es veié afavorida pel mateix sentit confirmatori fort de tanmateix en l'accepció d'efectivament', tal com succeeix amb noresmenys. L'evolució d'aquest sentit de contrast és particular: sorgit al segle XVII quedà arraconat a finals del XVIII per tornar a aparèixer al xIx i consolidar-se al xx, ajudat per la intervenció estandarditzadora de la llengua que el situa «fins i tot, en registres orals mitjanament formals» (p. I28).

Caplletra 71 (Tardor, 2021), p. 297-302 
El capítol quart està enfocat a l'estudi de l'evolució de dos connectors de contrast concessiu que tenen la seva gènesi en paraules que expressaven algun tipus d'emoció: a despit de, malgrat \{øldeltotlaixó\}. Quant a a despit de, l'autora descriu de manera detallada l'evolució des del sentit etimològic, heretat del llatí, del substantiu despit (< DESPICATUS 'menyspreu, desdeny'). En una primera etapa, despit entrà a formar part de la locució prepositiva a despit de, on manté el seu sentit etimològic i funciona com un substantiu que significa el menyspreu d'una persona vers altra. Es tracta, doncs, d'un valor intersubjectiu (Nuyts 2005; Narrog 2012) en què emissor i receptor estan implicats. Per les mateixes dates (segona meitat del segle XIII), es documenta despit en les locucions prepositives a-en despit dela $\{$ [POSSESSIU]\} despitla despit $\{[$ POSSESSIU]\} (a son despit / a despit seu), que tenen un valor de "[CONTRAVOLUnTAT] d'irritació produïda pel menyspreu o per la major vàlua d'altri» (p. I52). Aquestes estructures prepositives, que indiquen que un fet succeeix contra la voluntat del subjecte, suposen una tendència a la subjectivització. $A$ despit de entrà en crisi al segle XvII, quan deixa de documentar-s'hi, tret d'algunes mostres lexicogràfiques. Així, el següent pas evolutiu el trobem ja en plena Renaixença: entre els segles XIX-Xx a despit de es troba ja amb valor concessiu, probablement a causa d'una recreació que segueix el model d'a pesar $d e$, forma que "havia romàs en ús en català» (p. I60). El model normatiu possiblement explica l'ús exclusivament culte d'aquesta forma. Martínez assenyala també la possible influència del francès, on existia una forma paral-lela en dépit de (p. 164), però també de l'italià o de l'anglès (in spite of, despite); llengües que varen ser traduïdes amb certa freqüència en aquest període de finals del xIx i començaments del xx.

Lúltim connector de què s'ocupa Caterina Martínez, malgrat, té una història en certa manera paral-lela a la d'a despit de. S'origina en una expressió d'emoció, que Martínez descriu com a DESPLAER i evoluciona amb un sentit concessiu, després d'haver caigut en desús en l'edat moderna i haver estat rescatat per la llengua normativa en l'edat contemporània, quan va ser "retocat" formalment i dotat de patrons sintàctics nous» (p. 174).

L'evolució dels connectors de què s'ocupa Caterina Martínez posa en relleu la transcendència del context sociocultural en l'evolució de la llengua, en general, i de la gramàtica, en particular. Els connectors estudiats mostren la importància de la normalització lingüística del català, filla de la Renaixença, en la seva història. Aquestes evolucions fan tornar sobre la idea que els paràmetres de canvi descrits des de la gramaticalització no sempre han de ser seguits al peu de la lletra, ja que l'evolució de les llengües queda fortament condicionada pels factors socials, culturals i polítics (Garachana 2019). L'impacte que la Decadència va tenir en l'ús culte del català 
condiciona la trajectòria evolutiva de la llengua, així com la cerca d'exemples de les construccions que s'estudien. Aquest període, marcat per un ús molt minoritari de la llengua en els registres formals, va anar seguit de la Renaixença, que portà a la normativització moderna del català. La creació d'una norma del català culte va suposar un període de revitalització de la llengua que donà lloc a la recuperació de formes lingüístiques perdudes i, a voltes, a la seva reelaboració amb valors i formes que no es poden rastrejar en els textos. Lluny de devaluar l'estudi de l'evolució de la gramàtica de les llengües, fets com aquest són il.lustratius de com les teories lingüístiques no exhaureixen totes les possibles explicacions quan de canvi gramatical es parla. En aquest punt, el cas més il.lustratiu és el del connector nogensmenys. El tradicional oblit d'una forma que devia ser pròpia de la llengua escrita va motivar una substitució no fonamentada en l'evolució lingüística, sinó en una anàlisi errònia de noresmenys com a castellanisme. Aquesta interpretació esbiaixada va motivar l'aparició de nogensmenys.

Per acabar, volem ressaltar que la descripció raonada que la Caterina Martínez fa de l'evolució dels connectors que estudia inclou informació detallada sobre els seus contextos d'ús. En conseqüència, el seu treball s'insereix plenament dins els paràmetres d'estudi de la lingüística de la variació d'arrel coseriana. En efecte, la descripció acurada que fa del tipus de text i de la posició que ocupa cada forma en la seqüència textual encaixa perfectament en el concepte de tradicionalitat discursiva tal com aquesta és descrita a Koch (1997), Kabatek (2018) i López Serena (2020). Per a un plantejament romànic de les tradicions discursives, $v g$. Winter-Froemel \& Octavio de Toledo (202I).

En síntesi, amb l'Origen i evolució dels connectors de contrast en català, el lector es trobarà no només amb una obra que descriu l'evolució de quatre connectors de contrast, sinó també, i sobretot, amb un treball que permet extreure conclusions teòriques de gran rellevància.

Mar Garachana Universitat de Barcelona margarachana@ub.edu ORCID oooo-0003-4923-3254

\section{REFERÈNCIES BIBLIOGRÀFIQUES}

Anscombre, J. C. \& O. Ducrot (1994) L'argumentation dans la langue, Brussel.les, Mardaga. 
Garachana, M. (2018) «New Challenges in the Theory of Grammaticalization. Evidence from the Rise of Spanish Counter-argumentative Markers», dins Ó. Loureda \& S. Pons (eds.), New Insights into the Grammaticalization of Discourse Markers, Leiden, Brill, p. 198-230.

- (2019) «Més enllà de la gramaticalització: el desenvolupament del marcador discursiu no obstant això en català», Caplletra. Revista Internacional de Filologia, 66, p. 137-I62. [En línia: https://www.scipedia.com/public/Garachana_2019a.]

Geeraerts, D. (1997) Diachronic Prototype Semantics. Contribution to Historical Lexicology, Oxford, Clarendon Press.

Каватек, J. (2018) Lingüistica coseriana, lingüística histórica, tradiciones discursivas, Madrid, Iberoamericana.

Koch, P. (1997) «Diskurstraditionen: zu ihrem sprachtheoretischen Status und ihrer Dynamik», Gattungen mittelalterlicher Schriftlichkeit, Tubingen, Narr, p. 43-79.

López SerenA, A. (2020) «La tradicionalidad discursiva como materia y las tradiciones discursivas como objeto de estudio», dins A. López \& S. del Rey (eds.), Tradiciones discursivas y tradiciones idiomáticas en la historia del español moderno, Berlín, Peter Lang.

Narrog, H. (20I2) Modality, Subjectivity, and Semantic Change, Oxford, Oxford University Press.

NuYTs, J. (2005) «Modality: overview and linguistic issues», dins W. Frawley (ed.), The expression of modality, Berlín, De Gruyter, p. I-26.

Traugott, E. (20IO) "Revisiting Subjectification and Intersubjectification», dins K. Davidse, L. Vandelanotte \& H. Cuyckens (eds.), Subjectification, intersubjectification and Grammaticalization, Berlín, Mouton de Gruyter, p. 29-70.

Traugott, E. \& R. Dasher (2002) Regularity in Semantic Change, Cambridge, Cambridge University Press.

Winter-Froemel, E. \& Á. Octavio de Toledo (202I) Manual of Discourse Traditions in Romance, Berlín, De Gruyter. 